\title{
PENYULUHAN DARING: ETIKA KOMUNIKASI MENGGUNAKAN EMAIL UNTUK MENUNJANG EFEKTIVITAS KOMUNIKASI DALAM BISNIS
}

\author{
Melly Ridaryanthi, Bambang Joko Priyono \\ melly@mercubuana.ac.id \\ IImu Komunikasi, Fakultas IImu Komunikasi, Universitas Mercu Buana \\ Diterima 3 Maret 2021, dipublikasikan 25 Oktober 2021
}

\begin{abstract}
Abstrak
Banyak badan usaha baik itu usaha besar, menengah maupun kecil yang memanfaatkan internet sebagai sarana untuk menjalankan usahanya. Penggunaan email dipilih sebagai salah satu medium komunikasi dalam konteks bisnis maupun pemasaran. Email dapat digunakan untuk berkomunikasi antara pemilik usaha dengan konsumen atau calon konsumen, atau bahkan sesama pemilik usaha untuk berkomunikasi terkait bidang usahanya. Komunikasi menggunakan email ini dapat digunakan dalam konteks komunikasi bisnis dalam interaksi antarpribadi maupun dalam kelompok. Email dapat mengakomodir kebutuhan pengiriman dokumen, gambar, maupun video yang diperlukan dalam menjalani bisnis maupun pemasaran. Seperti komunikasi dalam konteks antarpribadi maupun kelompok, diperhatikan tata cara dan etika komunikasi yangdilakukan melalui pengunaan email. Komunikasi yang dilakukan secara langsung akan terikat dengan budaya dan aturan, termasuk juga etika. Begitu pula ketka komunikasi yang dilakukan dimediasi menggunakan media, dalam hal ini adalah email. Memahami email dan penggunaan fitur-fitur yang dimilikinya sebagai satu alat komunikasi perlu dipelajari sebelum seseorang menggunakannya. Selain itu, etika dalam berkomunikasi ketika menggunakan email juga menjadi satu hal penting yang perlu diperhatikan. Remaja sebagai pengguna aktif media elektronik dan digital dilihat perlu mendapatkan bekal literasi penggunaan email sesuai dengan etika yang berlaku. Berdasarkan dasar pemikiran tersebut, maka literasi etika komunikasi dalam menggunakan email untuk menunjang efektivitas komunikasi dalam bisnis perlu diberikan kepada siswa sekolah menengah sebagai bekal literasi dan kemahiran berkomunikasi mereka dalam dunia profesional. Literasi media digital terkait etika komunikasi menggunakan email untuk menunjang efektivitas komunikasi bisnis akan diberikan kepada siswa SMKN 1 Kota Tangerang khususnya siswa dengan peminatan Bisnis Daring dan Pemasaran sebagai bekal ketrampilan berkomunikasi mereka.
\end{abstract}

Kata Kunci: Etika Komunikasi, Email, Komunikasi Bisnis

\section{PENDAHULUAN}

Saat ini, sebagian besar komunikasi dan transaksi bisnis dilakukan melalui Computer Mediated Communication (CMC) di mana email menjadi salah salah satu jenis CMC yang paling dikenal (Madanchian \& Taherdoost, 2015). Fitur email dikenal sebagai salah satu fasilitas komunikasi elektronik yang dapat dimanfaatkan untuk kegiatan bisnis dan pemasaran dengan biaya yang murah (Oetomo 2009). Email telah menjadi aplikasi utama yang digunakan dalam komunikasi sehari-hari baik itu dalam komunikasi antarpribadi maupun dalam keperluan bisnis (Bahgat et al. 2018). Bahkan email dikatakan memainkan peran penting dalam membangun dan memelihara hubungan bisnis, baik itu komunikasi di dalam perusahan maupun dengan pihak luar. Email digunakan untuk mengirim berita, informasi, surat, dokumen, gambar, dan data yang disampaikan secara elektronik.

Banyak badan usaha baik itu usaha besar, menengah maupun kecil yang memanfaatkan internet sebagai sarana untuk menjalankan usahanya. Penggunaan email atau surat elektronik dipilih sebagai salah satu medium komunikasi dalam konteks bisnis maupun pemasaran. Teknologi informasi memainkan peran yang sangat penting dalam organisasi di mana email biasa digunakan 
sebagai salah satu alat komunikasi. Email telah menggantikan komunikasi konvensional seperti penggunaan surat, selain juga email telah menjadi alat komunikasi dalam lingkungan bisnis. Email dapat digunakan untuk berkomunikasi antara pemilik usaha dengan konsumen atau calon konsumen, atau bahkan sesama pemilik usaha untuk memudahkan penyampaian informasi terkait bidang usahanya. Komunikasi menggunakan email ini dapat digunakan dalam konteks komunikasi bisnis dalam interaksi antarpribadi maupun dalam kelompok.

Dalam sebuah organisasi, email dapat digunakan sebagai sarana komunikasi yang efektif sebagai bagian dari strategi komunikasi internal perusahaan untuk meningkatkan hubungan antar staf, di samping juga meningkatkan produktivitas (Madanchian \& Taherdoost, 2015). Keberadaan internet dan berbagai fasilitas komunikasi di dalamnya telah memberikan banyak pilihan untuk berkomunikasi, sehingga keadaan ini memberikan dampak pada cara seseorang berkomunikasi. Hal yang paling penting dari kegiatan komunikasi yang dilakukan dengan bermediasikan computer seperti email, instant messaging maupun media sosial adalah fasilitas internet yang terhubung ke perangkat seperti smartphone (Fauzi 2017). Budaya organisasi dapat memengaruhi cara orang berkomuniaksi dalam suatu organisasi (Madanchian \& Taherdoost, 2015). Email masih dilihat sebagai media komunikasi yang paling umum digunakan di dalam suatu organisasi. Penggunaan email memudahkan dalam berkomunikasi khususnya di lingkungan pekerjaan.

Email merupakan salah satu alat komunikasi yang dapat mengirimkan pesan dengan cepat (Ali \& David, 2014). Email dapat mengakomodir kebutuhan pengiriman dokumen, gambar, maupun video yang diperlukan dalam menjalani bisnis maupun pemasaran. Efektivitas dalam berkomunikasi, khususnya dalam konteks interpersonal, dalam perspektif humanistik diperlukan adanya keterbukaan, perilaku positif, empati dan kesamaan terkait perilaku dan pengalaman (Hutagalung 2017). Komunikasi dikatakan efektif dengan memastikan prosesnya berlangsung secara praktis, faktual, singkat, jelas dan persuasif (Thill \& Bovee 2013). Hal ini tidak hanya berlaku dalam konteks komunikasi yang dilakukan saat bertatap muka secara langsung.

Tapscott, seperti dikutip Fauzi (2017), berpandangan bahwa salah satu norma yang dianut oleh generasi internet adalah kebebasan. Tidak boleh dilupakan bahwa komunikasi yang dilakukan dengan bermediasikan komputer juga melibatkan hubungan individu-individu yang terlibat di dalam komunikasi tersebut. Dengan begitu unsur-unsur yang menunjang efektivitas dalam berkomunikasi harus diperhatikan terkait isi pesan, cara penyampaian dan termasuk pula etika dalam berkomunikasi. Kesopanan dan ketidaksopanan dalam membuka dan menutup email menjadi sesuatu yang jarang diperhatikan, khususnya dalam konteks akademik yaitu komunikasi antara dosen dengan mahasiswa. Lebih jauh lagi, walaupun pengunaan email sudah biasa dilakukan, tetapi kesalahan dalam beretika ketika berkomunikasi melalui internet (internet etiquette/netiquette) masih sering terjadi (Kacerauskas 2019). Hal ini tidak menutup kemungkinan akan terus terjadi bahkan dalam konteks komunikasi profesional di kemudian hari, dalam urusan bisnis, semisal.

Etika adalah perilaku yang diterima yang mengatur perilaku dalam masyarakat di mana hal ini menjadi salah satu perhatian penting yang difokuskan oleh sebuah perusahaan. Etika berkomunikasi menjadi cerminan wajah perusahaan di depan publik maupun rekanan bisnis. Etika dalam berkomunikasi termasuk juga keseluruhan informasi yang relevan dan yang dapat dipertanggung jawabkan kebenarannya (Thill \& Bovee 2013). Ditambahkan lagi, karena dalam komunikasi yang bermediasi komputer, di mana individu-individu yang terlibat tidak bertemu secara langsung, dikatakan bahwa media elektronik dan digital menjadi tempat berkembangnya etiket yang buruk dalam berkomunikasi

Penelitian-penelitian terkait kesopanan dan ketidaksopanan dalam berkomunikasi menggunakan email masih terus dilakukan dalam berbagai konteks sampai sekarang. Dengan begitu, literasi penggunaan media elektronik dan digital menjadi hal yang penting khususnya bagi para remaja yang banyak menggunakan media digital dalam kehidupan mereka sehari-hari (Briandana \& Dwityas, 2019). Literasi komunikasi dengan menggunakan media elektronik dan digital terkait dengan praktik maupun interaksi sosial yang terkandung di dalamnya. Dalam hal ini, etika berkomunikasi melalui email menjadi salah satu hal yang perlu dipahami. 
Siswa-siswa sekolah menengah sudah kenal penggunaan email sebagai medium berkomunikasi, setidaknya mereka memiliki email untuk syarat pembuatan akun-akun media sosial. Namun, literasi tentang penggunaan email yang benar sesuai etika yang berlaku perlu dengan serius diperkenalkan kepada mereka. SMKN 1 Kota Tangerang memiliki satu jurusan peminatan Bisnis Daring dan Pemasaran di mana literasi dan kemahiran berkomunikasi perlu dibekali kepada para siswa sejak dini agar terbiasa dengan penggunaan email sebagai alat komunikasi sesuai dengan etika penggunaannya. Hal ini menjadi justifikasi pentingnya dilaksanakannya penyuluhan terkait etika penggunaan email sebagai medium berkomunikasi dalam konteks komunikasi bisnis sebagai bekal bagi para siswa sekolah menengah untuk memasuki dunia professional.

Berdasarkan penelitian-penelitian terdahulu yang telah dirangkum dalam pemaparan latar belakang pelaksanaan kegiatan Pengabdian Pada Masyarakat, dapat dirumuskan bahwa email merupakan salah satu media komunikasi yang penting, khususnya pada penggunaannya dalam konteks bisnis dan pemasaran yang dilakukan sebuah organisasi. Penggunaan email dapat menjembatani hubungan interpersonal maupun kelompok dalam konteks bisnis. Selain keefektivan komunikasi yang perlu disoroti, penggunaan email tidak terlepas dari etika penggunaan yang harus dipahami oleh para pengguna email tersebut.

Penelitian terkait berkomunikasi menggunakan media elektronik dan digital, termasuk etika berkomunikasi terkait kesopanan dan ketidaksopanan menjadi hal-hal yang difokuskan oleh beberapa peneliti seperti Oetomo (2009), Ali \& David. (2014), dan Fauzi (2017). Remaja sebagai pengguna aktif media elektronik dan digital dilihat perlu mendapatkan bekal literasi penggunaan email sesuai dengan etika yang berlaku. Berdasarkan dasar pemikiran tersebut, maka literasi terkait etika komunikasi dalam menggunakan email untuk menunjang efektivitas komunikasi dalam bisnis perlu diberikan kepada siswa sekolah menengah sebagai bekal literasi dan kemahiran berkomunikasi mereka dalam dunia profesional.

Berdasarkan pemaparan rumusan masalah di atas, kegiatan Pengabdian Pada Masyarakat ini dilaksanakan untuk tujuan berikut: 1) Memperkenalkan fungsi email dalam konteks komunikasi bisnis dan 2) Meningkatkan literasi siswa terkait etika berkomunikasi melalui email.

\section{METODE}

Kegiatan ini dilaksanakan untuk membangun literasi komunikasi digital terkait pentingnya pemanfaatan email sesuai etika berkomunikasi dalam konteks komunikasi bisnis untuk menunjang efektivitas komunkasi melalui pemberian materi. Kegiatan diakukan melalui dua aktivitas berikut: 1) Ceramah terkait etika komunikasi menggunakan email untuk menunjang efektivias komunikasi bisnis dan 2) Simulasi pembuatan dan penggunaan email sesuai etika komunikasi yang telah dipaparkan.

\section{HASIL DAN PEMBAHASAN}

Persiapan dan perencanaan pelaksanaan kegiatan dilaksanakan dalam satu tim dosen berdasarkan tema-tema yang serupa. Tim ini menyiapkan materi terkait Keberlangsungan Bisnis sesuai dengan salah satu jurusan yang ada di SMKN 1 Kota Tangerang. Dengan dibantu oleh koordinator, komunikasi dengan pihak sekolah dibangun untuk menentukan waktu penelitian dan teknis pelaksanaan.

Dikarenakan masih dalam pandemi, pelaksanaan kegiatan pengabdian ini dilakukan secara daring. Waktu yang ditentukan juga berdasarkan pada kesediaan pihak sekolah karena SMKN 1 Kota Semarang berada dalam masa aktif kegiatan belajar mengajar. Salah satu persiapan yang dilakukan adalah melalui perangkat sosialisasi kegiatan berupa poster. Pada pelaksanaannya, terdapat tiga tim dosen sebagai pembicara. Penyuluhan daring ini dihadiri oleh 21 siswa SMKN 1 Kota Tangerang, perwakilan guru dan mahasiswa Universitas Mercu Buana yang membantu dalam koordinasi pelaksanaan kegiatan.

\section{Implementasi Kegiatan}

Penyuluhan daring dengan topik penggunaan email dalam bisnis ini dilakukan dengan memberikan pemaparan materi yang sudah disediakan tim pemberi materi. Di awal kegiatan dilakukan kegiatan interaktif menggunakan www.menti.com untuk mengajak peserta kegiatn untuk 
proses brainstorming terkait hal-hal apa saja yang perlu diperhatikan dalam menggunakan email. Hasilnya dapat dilihat pada gambar 1.

Go to www.menti.com and use the code 4062314

\section{Apa saja yang perlu diperhatikan saat mengirim email?}

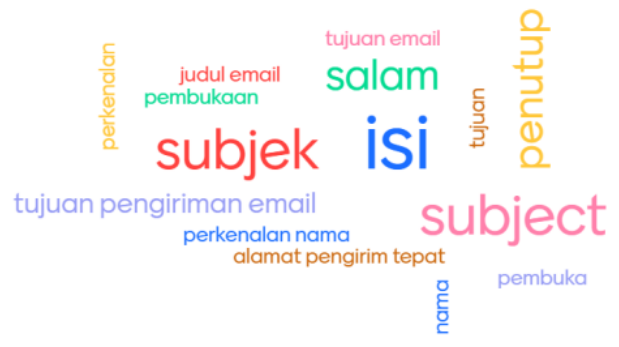

Gambar 1 Aktivitas Interaktif dengan Peserta Menggunakan www.menti.com

Brainstorming ini proses awal yang dilakukan untuk memastikan bahwa peserta mengetahui topik yang akan dipaparkan dan memiliki pengetahuan tentang email. Hal ini membantu dalam proses penyampaian materi karena tim pemateri bisa menarik pengalaman dan pengetahuan peserta dalam proses pemaparan materi agar mereka merasa terlibat. Kegiatan praktik tidak dapat dilakukan karena keadaan yang tidak kondusif untuk pelaksanaannya. Namun begitu, materi yang disediakan juga bisa mengakomodir keperluan penyuluhan ini agar peserta secara visual dapat menangkap materi terkait penggunaan email tersebut. Dengan begitu, secara kognitif bisa dipahami dengan baik fungsi dari email dan komponennya, sehingga dapat diaplikasikan kemudian.

\section{Waktu Pelaksanaan Kegiatan}

Disebabkan masih dalam kondisi pandemi, maka pelaksanaan kegiatan dilakukan secara daring dengan media Zoom Meeting. Adapun waktu pelaksanaannya dilaksanakan pada hari Selasa, 9 Februari 2021, pukul 13.00-15.00 WIB dilaksanakan secara daring melalui Zoom Meeting.

Pada kesempatan pemaparan materi, pemaparan diawali dengan brainstorming diikuti dengan penjelasan proses komunikasi yang efektif. Materi terkait pentingnya penulisan yang spesifik, pesan yang singkat namun jelas, memahami jarak hubungan dalam konteks profesional, penggunaan bahasa yang tepat sesuai konteks hubungan dan memerhatikan etika merupakan aspek-aspek yang dibahas sebagai pembuka.

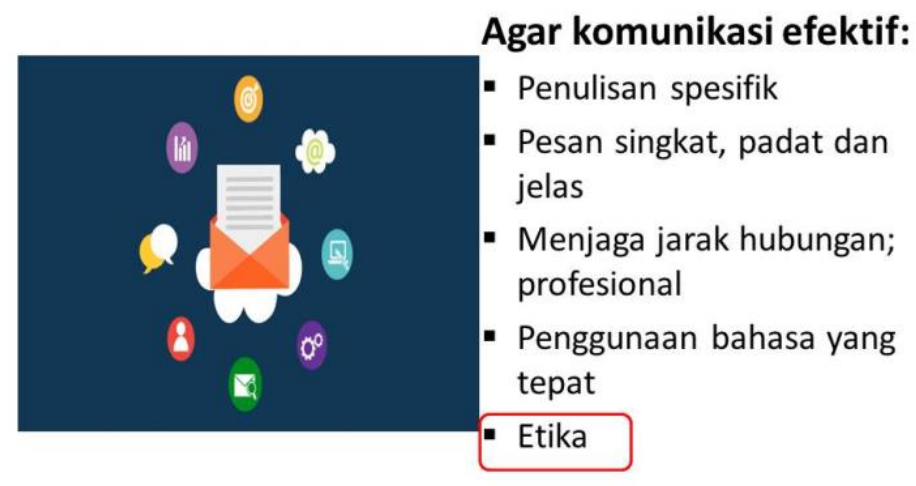

Gambar 2 Pemaparan Komunikasi Efektif 
Dalam pembahasan mengenai etika, hal inilah yang ditekankan sebagai inti dari tema penyuluhan ini bahwa etika dalam berkomuniaksi, terutama dalam menggunakan email, adalah sesuatu yang mungkin sudah diketahui khalayak namun terkadang dilupakan atau terlupakan. Contoh-contoh pendukung diberikan agar kelompok sasaran penyuluhan ini mendapatkan gambaran konkrit tentang kasus-kasus yang masih sering terjadi terkait penggunaan email yang kurang tepat.

Pemaparan dilanjutkan dengan hal-hal apa saja yang perlu diperhatikan dalam menggunakan email. Sedikit pengenalan tentang bagaimana pentingnya identitas pengirim dijelaskan kepada khalayak sasaran penyuluhan ini. Dilanjutkan dengan komponen pada email yang perlu dipahami terkait alamat tujuan, penggunaan Copy Carbon dan juga Blind Copy Carbon, agar tidak salah lagi dalam menggunakannya. Pemaparan dilanjutkan tentang pentingnya penulisan subjek email dan badan email yang efektif.

\section{- Identitas Pengirim \\ - Nama penuh \\ - Alamat email \\ - Foto profile}

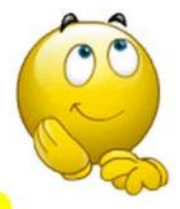

- Alamat email tujuan

- Email utama yang dituju

- CC (Carbon Copy)

- BCC (Blind Carbon Copy)

\section{- Subjek email}

\section{- Badan email}

- Pembuka

- Isi

- Penutup

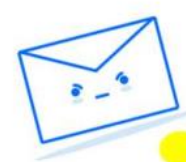

Gambar 3 Pemaparan Komponen dalam Email ke-1

Pada pemaparan ini, pemateri menunjukkan bagian-bagian email yang dibahas agar khalayak dapat menangkapnya secara visual sehingga materi yang disampaikan dapat lebih dipahami walaupun tidak ada praktik and hands on pada penyuluhan kali ini disebabkan keadaan yang tidak memungkinkan. Setelah komponen-komponen tersebut, hal terakhir yang menjadi topik pemaparan adalah terkait cara membalas email. Khalayak dikenalkan dengan fitur reply dan reply all yang tersedia pada email, dan juga fungsi dari masing-masingnya. Cara membalas email menjadi salah satu hal yang juga perlu diperhatikan karena tidak semua email yang diterima harus dibalas kepada semua alamat email yang tertera. Penerima email hendaklah memerhatikan konteks isi email untuk memastikan apakah perlu fitur reply all atau reply saja.

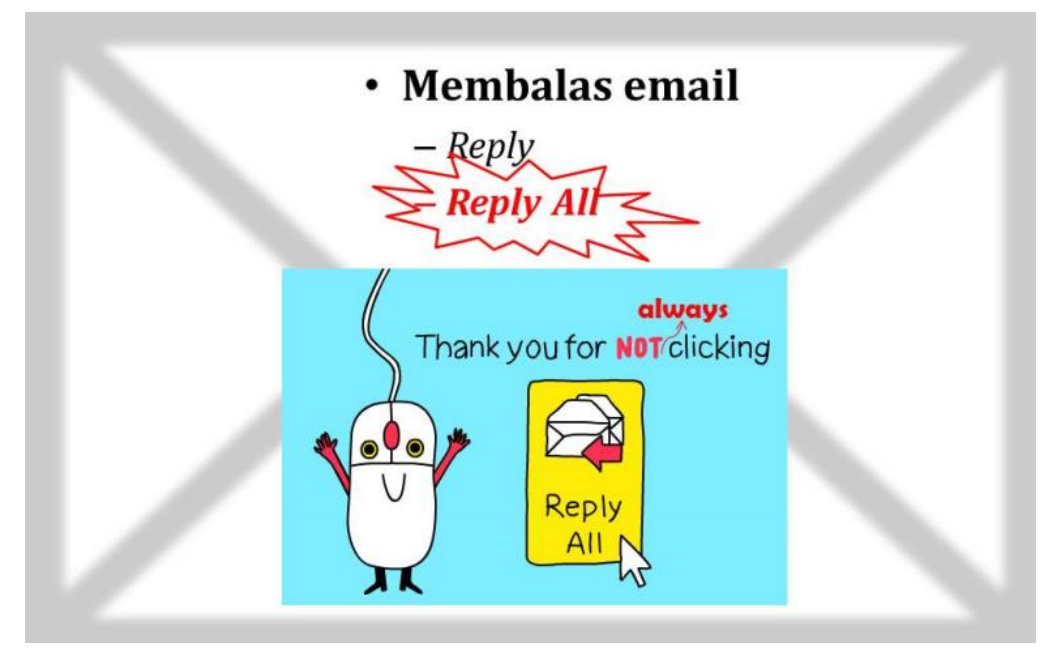

Gambar 4 Pemaparan Komponen dalam Email ke-2 
Penyuluhan diakhiri dengan sesi tanya jawab. Pertanyaan disampaikan baik secara langsung oleh peserta maupun melalui kolom chat yang tersedia. Dalam pelaksanaan penyuluhan daring ini, peserta diminta mengisi kuesioner untuk mengetahui persepsi mereka terhadap pelaksanaan penyuluhan daring. Terdapat sepuluh (10) komponen pertanyaan dalam kuesioner tersebut terkait pelaksanaan kegiatan, berikut adalah dua komponen penting yang ingin tim penulis laporkan terkait isi materi yang disampaikan dan kompetensi pembicara.

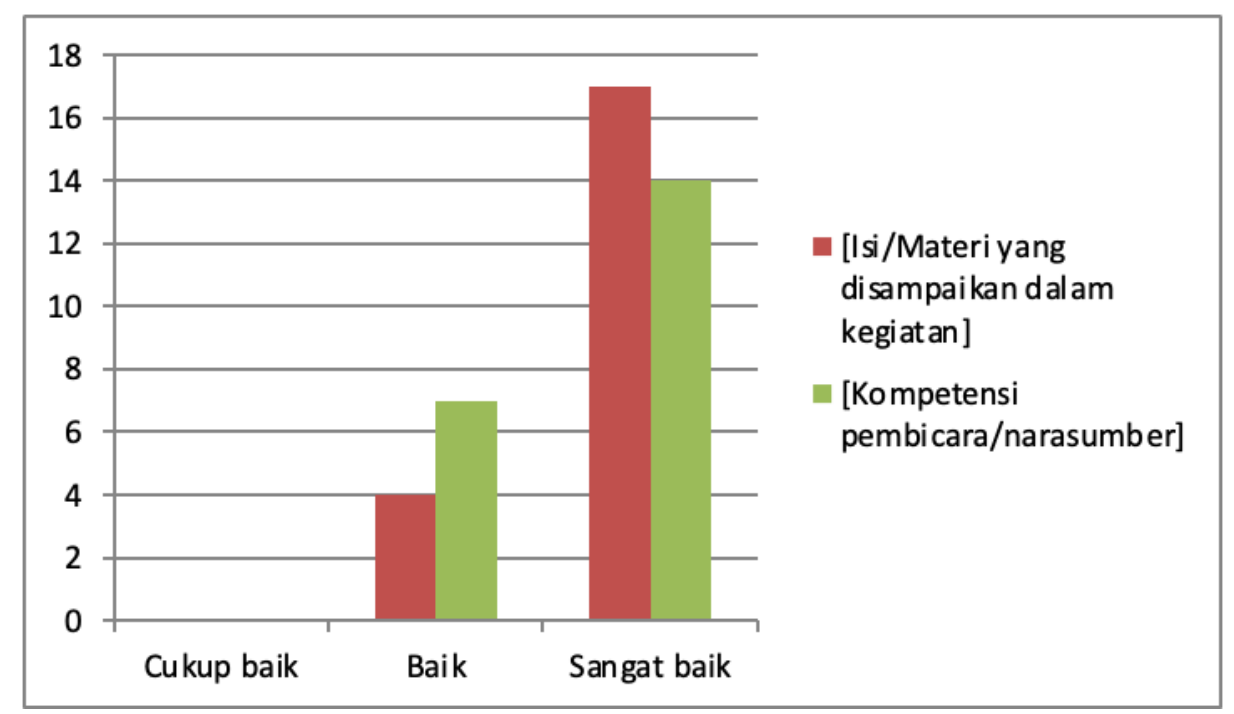

Gambar 5 Feedback Kegiatan Berdasarkan Isi Materi dan Kompetensi Pembicara

Berdasarkan pada bagan yang terdapat pada Gambar 5 Feedback kegiatan berdasarkan isi materi dan kompetensi pembicara, mayoritas peserta memberikan respon bahwa kualitas materi yang diberikan dan pembicara sangat baik. Hal ini tentu saja merupakan respon positif yang diberikan oleh pihak peserta terkait kebermanfaatan pelaksanaan penyuluhan berdasarkan isi materi dan pematerinya.

\section{KESIMPULAN}

Berdasarkan pelaksanaan penyuluhan dan realitas bahwa email masih dengan aktif digunakan dalam dunia profesional, dalam konteks penyuluhan ini adalah dunia bisnis, maka pelaksanaan penyuluhan ini sangat relevan bagi khalayak sasaran yang merupakan siswa SMK pada jurusan Keberlangsungan Bisnis. Dunia bisnis saat ini tidak dapat lagi dipisahkan dengan dunia digital, termasuk penggunaan email. Email yang digunakan dalam konteks komunikasi internal dalam sebuah organisasi, maupun komunikasi ke luar, masih perlu diperhatikan etika penggunaannya. Memberikan penyuluhan kepada siswa SMK yang memang dipersiapkan untuk terjun ke dunia bisnis setelah lulus merupakan sasaran yang tepat. Dengan begitu, materi dan pelaksanaan penyuluhan dengan topik etika komunikasi menggunakan email untuk menunjang efektivitas komunikasi dalam bisnis adalah relevan dan krusial. Melalui laporan ini dapat disampaikan bahwa objektif pelaksanaan kegiatan ini tercapai (i) memperkenalkan fungsi email dalam konteks komunikasi bisnis dan (ii) meningkatkan literasi siswa terkait etika berkomunikasi melalui email.

Karena pelaksanaan penyuluhan ini hanya dapat dilakukan secara daring, sehingga tidak dapat dipastikan bahwa semua siswa dapat menggunakan komputer atau laptop untuk melakukan simulasi langsung pada saat penyuluhan. Di masa mendatang, apabila memungkinkan, pelaksanaan dilakukan di laboratorium komputer sehingga semua siswa mendapat kesempatan untuk mengoperasikan sendiri penggunaan email sebagai bentuk praktik dalam penyuluhan. Selain dari itu, selama penggunaan email masih relevan dalam bidang bisnis, materi ini bisa terus diberikan kepada siswa-siswa kelas 12 yang sudah akan menyelesaikan pendidikan tingkat menengahnya. 


\section{UCAPAN TERIMA KASIH}

Tim pelaksana PPM ini ingin menyampaikan terima kasih kepada Universitas Mercu Buana melalui Pusat Pengabdian Pada Masyarakat atas kesempatan dan kepercayaannya kepada kami untuk dapat menjalankan salah satu Tri Dharma Perguruan Tinggi yaitu Pengabdian Pada Masyarakat.

\section{DAFTAR PUSTAKA}

Ali, H. \& David, M.K. (2014). "Hello and good day to you dear Dr. ..." Greetings and closings in Supervisors-Supervisees Email Exchanges. Procedia - Social and Behavioral Science 118, 8593.

Bahgat, E. M., Rady, S., Gad, W., \& Moawad, I. F. (2018). Efficient email classification approach based on semantic methods. Ain Shams Engineering Journal 9, 3259-3269.

Oetomo, B.S.D. 2009. Efektivitas Email untuk Pemasaran. Jurnal EKSIS 2(2), 26-31.

Hutagalung, I. (2017). The Function of Interpersonal Communication in Conflict Management Organization. SHS Web of Conferences 33.

Kacerauskas, T. (2019). Ethics in Business and Communicatin: Common Ground or Incommensurable? Business Administration and Management 22(1), 72-81.

Madanchian, M., \& Taherdoost, H. (2016). Persuing of Organizational Culture Effects on E-mail Communication. Procedia Technology 22, 1076-1083.

Fauzi, R. (2017). Perubahan Budaya Komunikasi pada Pengguna WhatsApp di Era Media Baru. Jurnal IImu Komunikasi Efek - JIKE 1 (1).

Briandana, R. \& Dwityas, N.A. (2019). Media Literacy: An Analysis of Social Media Usage among Millenials. International Journal of English Literature and Social Sciences 4(2), 488-496.

Thill, J. V., \& Bovee, C. L. (2013). Excellence in Business Communication Tenth Edition. New Jersey: Pearson. 